\title{
USABILITY TESTING PADA OFFICE ADD-INS DALAM MENGINTEGRASIKAN SISTEM REKONSTRUKSI MATERI DAN SISTEM MANAJEMEN PEMBELAJARAN
}

\author{
A.A. Gede Yudhi Paramartha1), I Gede Partha Sindu' ${ }^{2}$, Agus Aan Jiwa Permana ${ }^{3)}$ \\ Program Studi Manajemen Informatika ${ }^{1)}{ }^{3)}$ \\ Program Studi Pendidikan Teknik Informatika ${ }^{2}$ \\ Universitas Pendidikan Ganesha \\ yudhi.paramartha@undiksha.ac.id ${ }^{1)}$,partha.sindu@undiksha.ac.id ${ }^{2}$, agus.aan@undiksha.ac.id ${ }^{3)}$
}

\begin{abstract}
The development of electronic learning materials requires various applications that are used to support electronic learning. The lecturer makes the material by utilizing a document processing application to create learning material, using a search engine to obtain teaching materials, and a Learning Management System to publish learning material. This causes the lecturer to have to move to one application to another application. In previous research, to overcome these problems, an add-ins was developed in Microsoft Office PowerPoint that integrates Learning Management Systems as a media for publishing learning materials, and Material Reconstruction System as a source of reusable teaching materials by utilizing the search engines provided. These add-ins function as an intermediary between the two systems with Microsoft PowerPoint, so users only need to use one application to develop learning material and publish it to e-learning. In this study, the add-ins that have been developed are tested using the usability testing method. Usability testing is done to determine the level of user satisfaction in using the add-ins and obtain feedback for system improvements. The method used is Retrospective Think Aloud method to obtain feedback from users, and the System Usability Scale to determine the level of user satisfaction in using the add-ins. The results showed that users were satisfied with the add-ins that had been developed. in addition, feedback from users was also successfully obtained and recommendations for add-ins improvements were made based on these recommendations.
\end{abstract}

Keywords : Learning Management System, Office Add-ins, Usability Testing

\begin{abstract}
ABSTRAK
Pengembangan materi pembelajaran elektronik membutuhkan berbagai aplikasi yang digunakan untuk mendukung pembelajaran elektronik. Dosen membuat materi dengan memanfaatkan aplikasi pengolah dokumen untuk membuat materi, menggunakan mesin pencari untuk memperoleh bahan ajar, dan Sistem Manajemen Pembelajaran untuk mempublikasikan materi pembelajaran. Hal ini menyebabkan dosen harus berpindah ke satu aplikasi ke aplikasi yang lain. Pada penelitian sebelumnya, untuk mengatasi permasalahan tersebut, dikembangkan sebuah add-ins di Microsoft Office PowerPoint yang mengintegrasikan Sistem Manajemen Pembelajaran sebagai media publikasi materi pembelajaran, dan Sistem Rekonstruksi Materi sebagai sumber bahan ajar dengan memanfaatkan mesin pencari yang disediakan. Add-ins tersebut berfungsi sebagai perantara antar kedua sistem tersebut dengan Microsoft PowerPoint, sehingga pengguna hanya perlu menggunakan satu aplikasi untuk mengembangkan materi pembelajaran hingga mempublikasikan materi tersebut ke e-learning. Pada penelitian ini, add-ins yang telah dikembangkan diuji dengan menggunakan metode usability testing. Usability testing dilakukan untuk mengetahui tingkat kepuasan pengguna dalam menggunakan add-ins dan memperoleh umpan balik untuk perbaikan sistem. Metode yang digunakan adalah metode Retrospective Think Aloud (RTA) untuk memperoleh dari pengguna, dan System Usability Scale (SUS) untuk mengetahui tingkat kepuasan pengguna dalam menggunakan add-ins. Hasil penelitian menunjukkan bahwa pengguna merasa puas dengan add-ins yang telah dikembangkan. selain itu, umpan balik dari pengguna juga berhasil diperoleh dan dibuatkan rekomendasi perbaikan berdasarkan rekomendasi tersebut.
\end{abstract}

Kata kunci: Sistem Manajemen Pembelajaran, Office Add-ins, Usability Testing 


\section{PENDAHULUAN}

Keberhasilan penerapan pembelajaran elektronik sejalan dengan bagaimana teknologi digunakan dengan efektif dan efisien . Teknologi yang dimaksud di sini adalah teknologi yang dapat menunjang pembelajaran elektronik seperti aplikasi perangkat lunak pendukung, mesin pencari, ketersediaan infrastruktur jaringan, kemampuan pengolahan data, dan lain sebagainya. Pada sisi perangkat lunak, banyak aplikasi maupun sistem informasi yang dapat digunakan dalam menunjang pembelajaran elektronik. Dosen dapat menggunakan berbagai aplikasi untuk membuat sebuah materi pembelajaran elektronik seperti aplikasi pengolah dokumen, spreadsheet, atau presentasi. Dosen juga dapat mencari materi sebagai bahan dokumen yang dibuat dengan memanfaatkan mesin pencari. Setiap materi yang dibuat oleh dosen selanjutnya diunggah ke sistem manajemen pembelajaran sehingga para siswa dapat mengunduh dan mempelajari materi dari mana saja [1].

Berbagai aplikasi dan sistem informasi telah dikembangkan untuk mendukung pembelajaran elektronik. Sebagai contoh, sistem rekonstruksi materi dikembangkan agar dosen dapat menggunakan kembali materi yang telah ada untuk dijadikan materi baru [2]. Dengan adanya sistem tersebut, dosen tidak perlu membuat materi dari awal lagi. Sistem tersebut memiliki sebuah fitur unik di mana sistem dapat memecah materi menjadi bagianbagian kecil sehingga mudah untuk digunakan kembali. Sistem tersebut juga menyediakan mesin pencari materi sehingga pengguna mudah untuk mencari materi yang diinginkan. Namun, sistem tersebut hanya memiliki fiturfitur yang terbatas yang belum selengkap aplikasi pengolah dokumen seperti Microsoft Office. Hal ini membuat pengguna masih harus tetap menggunakan aplikasi lain untuk mengolah materi lebih lanjut.

Untuk mengatasi keterbatasan tersebut, dikembangkan sebuah add-ins pada aplikasi Microsoft Office yang mengintegrasikan sistem rekonstruksi materi dan sistem manajemen pembelajaran. Add-ins ini berfungsi untuk memperluas atau menambahkan fitur standar yang ada di Microsoft Office. Fitur yang ditambahkan melalui add-ins ini yaitu: 1) kemampuan untuk mencari materi dan sistem rekonstruksi materi dengan memanfaatkan mesin pencari yang dimiliki, 2) kemampuan untuk mengunduh dan mengunggah materi ke sistem manajemen pembelajaran. Sistem manajemen pembelajaran yang didukung oleh add-ins ini adalah sistem yang berbasis Moodle. Gambar 1 adalah add-ins yang telah dikembangkan.

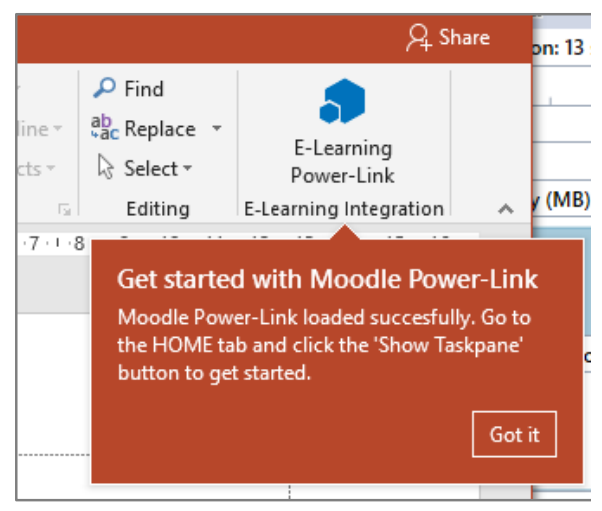

Gambar 1. Add-ins yang telah dikembangkan

Pengguna harus login dengan akun Moodle terlebih dahulu sebelum dapat menggunakan fitur-fitur yang ada pada addins. Setelah login, pengguna dapat memilih aksi diantaranya adalah 1) mengunduh dokumen dari Moodle, 2) mengunggah dokumen ke Moodle, 3) mencari materi. Gambar 2 adalah tampilan aksi setelah pengguna login.

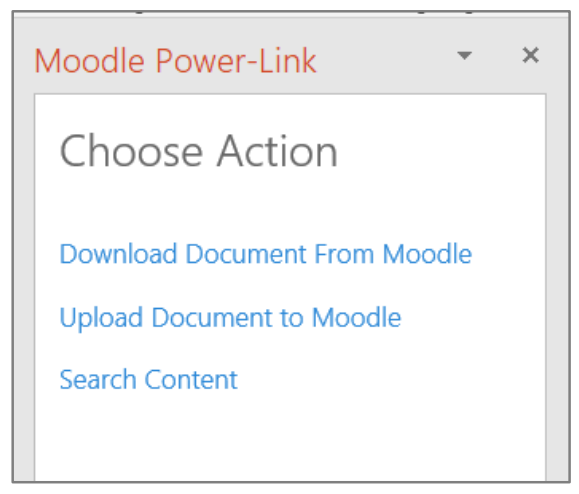

Gambar 2. Pilihan aksi pada add-ins

Jika aksi 1) dipilih, maka akan ditampilkan daftar kursus yang diikuti oleh pengguna. Pengguna dapat memilih salah satu kursus yang akan menampilkan daftar topik dan daftar materi yang ada pada setiap topik seperti terlihat pada Gambar 3. Perlu diketahui, bahwa materi yang ditampilkan hanya materi dengan format *.pptx. Pengguna dapat memilih salah satu materi sehingga dapat diedit di PowerPoint. 


\begin{tabular}{|l|}
\hline Moodle Power-Link \\
Video Test \\
General \\
\hline Topic 1 \\
\hline Presentation1.pptx \\
Presentation2.pptx \\
Topic 2 \\
\hline Presentation3.pptx \\
\hline Gambar 3. Tampt \\
\hline
\end{tabular}

Gambar 3. Tampilan daftar topik dan materi

Setelah pengguna melakukan pengeditan materi, pengguna dapat mengunggah materi tersebut ke Moodle dengan memanfaatkan fitur unggah materi. Proses yang dilakukan hampir sama dengan proses mengunduh materi, yaitu: memilih menu unggah dokumen, memilih kursus, memilih topik, dan menggunggah materi ke Moodle. Gambar 4 adalah tampilan unggah materi ke Moodle.

Fitur selanjutnya yang ada pada add-ins ini adalah kemampuan add-ins untuk mencari bahan materi dari materi yang telah diindeks oleh Sistem Rekonstruksi Materi. Fitur tersebut dapat dipilih melalui menu pencarian konten. Pengguna dapat memasukkan kata kunci dan menekan tombol "search". Add-ins akan berkomunikasi dengan Sistem Rekonstruksi Materi, dan selanjutnya mengembalikan daftar hasil pencarian. Pengguna dapat memilih salah satu hasil pencarian dan add-ins akan secara otomatis memasukkannya ke slide di PowerPoint. Gambar 5 adalah contoh hasil pencarian konten materi di add-ins.

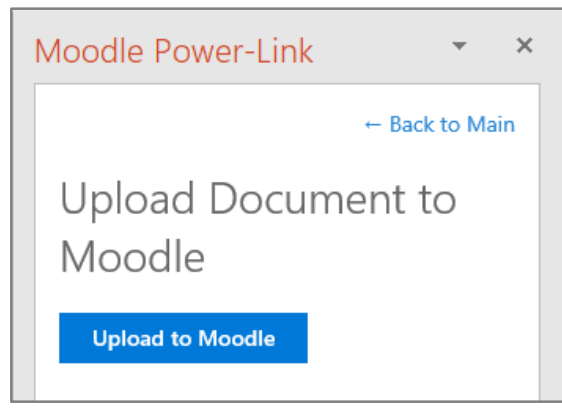

Gambar 4. Tampilan unggah materi ke Moodle

Berdasarkan hasil pengembangan add-ins di atas, dibutuhkan sebuah evaluasi untuk memastikan bahwa add-ins layak untuk digunakan. Sebuah perangkat lunak harus dievaluasi atau diuji sebelum dapat digunakan oleh orang banyak [3]. Ujicoba dilakukan untuk mendapatkan umpan balik dari pengembang sendiri atau dari calon pengguna. Umpan balik tersebut yang digunakan untuk memperbaiki perangkat lunak yang dikembangkan. Begitu juga dengan add-ins yang dikembangkan harus diuji terlebih dahulu sebelum digunakan oleh pengguna luas. Salah satu metode pengujian

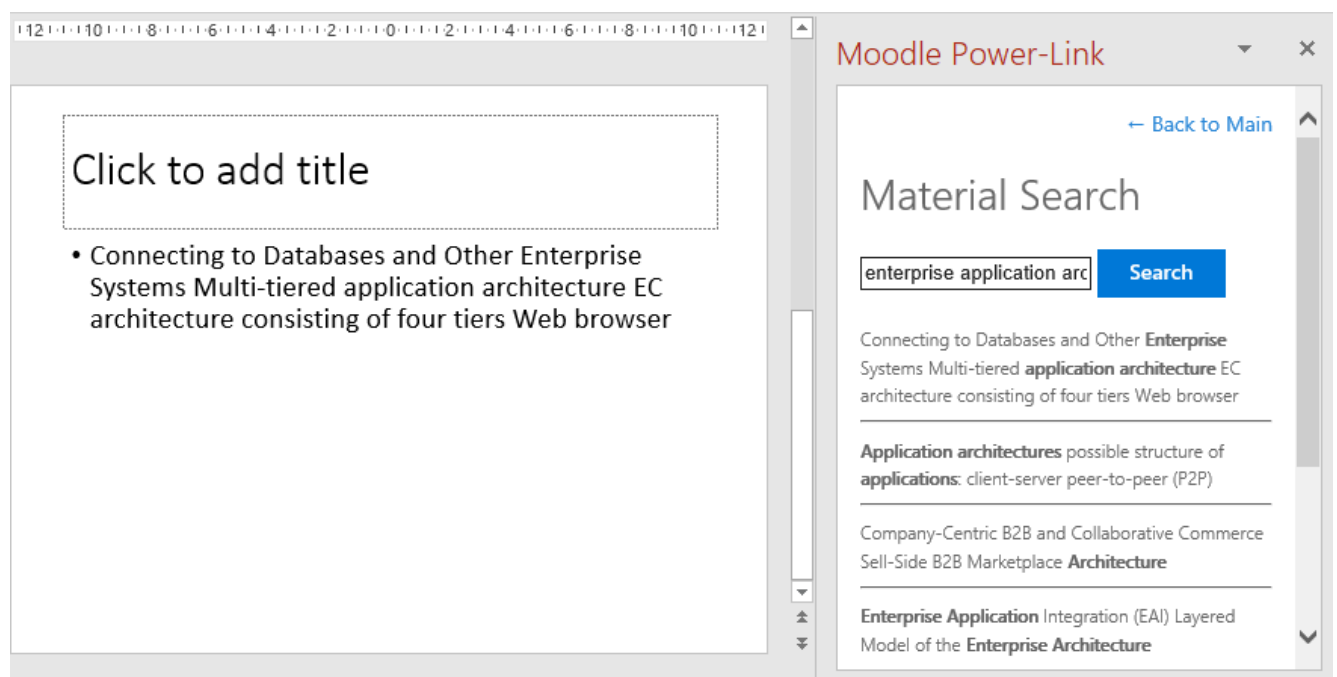

Gambar 5. Hasil pencarian pada fitur pencarian konten materi 
perangkat lunak adalah usability testing. Usability testing adalah sebuah metode pengujian perangkat lunak untuk mengevaluasi interaksi pengguna dengan sistem.

Berdasarkan pemaparan di atas, artikel ini membahas tentang bagaimana melakukan pengujian add-ins yang mengintegrasikan Sistem Manajemen Pembelajaran dengan Sistem Rekonstruksi Materi dengan menggunakan metode usability testing. Hasil ujicoba dijadikan sebagai rekomendasi perbaikan yang akan dibahas pada bagian akhir artikel ini.

\section{STUDI LITERATUR}

\section{Usability Testing}

Pengembangan perangkat lunak harus diuji terlebih dahulu. Pengujian pada umumnya adalah pengujian fungsional dengan metode white box testing di mana pengujian dilakukan oleh pengembang dan black box testing pengujian dilakukan oleh calon pengguna secara terbatas. White box dan black box testing adalah pengujian fungsional perangkat lunak tersebut [4]. Namun, sebenarnya masih ada jarak dalam antara fungsionalitas sistem dengan bagaimana kepuasan pengguna dalam menggunakan sistem tersebut [5]. Hal itulah yang dievaluasi pada usability testing. Menurut International Standards Organization (ISO-9241), usability adalah ukuran efektivitas, efisiensi, dan kepuasan pengguna dalam menggunakan suatu sistem untuk mencapai tujuan tertentu [6]. Usability testing digunakan untuk menganalisa permasalahan yang mungkin dihadapi oleh pengguna dalam menggunakan sistem, mengukur tingkat kepuasan pengguna dan mendapatkan rekomendasi perbaikan berdasarkan umpan balik dari pengguna [7]. Retrospective Think Aloud (RTA) dan System Usability Scale (SUS) adalah dua metode yang umum digunakan untuk melakukan evaluasi usability.

\section{System Usability Scale (SUS)}

SUS adalah sebuah metode untuk melakukan evaluasi kepuasan pengguna dalam menggunakan sebuah produk. SUS bersifat terbuka, terjangkau, mudah digunakan dan cepat namun sangat efektif untuk mengetahui kepuasan pengguna secara umum [8]. SUS dapat digunakan untuk jumlah responden yang relatif kecil dengan tingkat reliabilitas yang tinggi. Namun, SUS saja tidak cukup untuk mengukur usability sebuah sistem secara keseluruhan [9]. Dibutuhkan metode lain untuk dapat mendukung SUS. Beberapa metode yang dapat mendukung SUS diantaranya adalah RTA dan wawancara. SUS berisi kuesioner dengan 10 pertanyaan. Pertanyaan dengan nomor ganjil adalah pertanyaan positif, sedangkan pertanyaan dengan nomor soal genap adalah pertanyaan negatif. Setiap pertanyaan bernilai 0 sampai 4. Tabel 1 adalah daftar pertanyaan yang ada pada SUS [10].

Tabel 1. Daftar Pertanyaan pada SUS

\begin{tabular}{|c|c|c|c|c|c|c|}
\hline \multirow{2}{*}{ \# } & \multirow{2}{*}{ Items } & \multicolumn{3}{|c|}{ Stongly Disagree } & \multicolumn{2}{|c|}{ Strongly Agree } \\
\hline & & $\mathbf{0}$ & 1 & 2 & 3 & 4 \\
\hline 1 & I think that I would like to use this system frequently & & & & & \\
\hline 2 & I found the system unnecessarily complex & & & & & \\
\hline 3 & I thought the system was easy to use & & & & & \\
\hline 4 & $\begin{array}{l}\text { I think that I would need the support of a technical } \\
\text { person to be able to use this system }\end{array}$ & & & & & \\
\hline 5 & $\begin{array}{l}\text { I found the various functions in this system were well } \\
\text { integrated }\end{array}$ & & & & & \\
\hline 6 & $\begin{array}{l}\text { I thought there was too much inconsistency in this } \\
\text { system }\end{array}$ & & & & & \\
\hline 7 & $\begin{array}{l}\text { I would imagine that most people would learn to use } \\
\text { this system very quickly }\end{array}$ & & & & & \\
\hline 8 & I found the system very cumbersome to use & & & & & \\
\hline 9 & I felt very confident using the system & & & & & \\
\hline 10 & $\begin{array}{l}\text { I needed to learn a lot of things before I could get } \\
\text { going with this system }\end{array}$ & & & & & \\
\hline
\end{tabular}




\section{Retrospective Think Aloud (RTA)}

Salah satu tujuan dilaksanakan usability testing adalah untuk mengetahui bagaimana persepsi pengguna dalam menggunakan sistem. Salah satu metode yang dapat dilakukan untuk mengevaluasi hal tersebut adalah dengan menggunakan metode RTA. RTA adalah salah satu metode usability untuk melihat tingkah laku pengguna dalam menggunakan suatu dengan cara meminta pengguna untuk mengerjakan suatu tugas [11]. RTA memiliki kemampuan dalam menduplikasi tugas-tugas dalam dunia nyata, sehingga RTA sangat baik digunakan untuk mengetahui permasalahan-permasalahan yang dihadapi oleh pengguna dalam menggunakan sistem [12]. Tahapan yang dilakukan RTA adalah dengan memberikan tugas spesifik kepada responden dalam menggunakan sistem. Responden melakukan tugas tersebut tanpa dibantu oleh siapapun. Setelah responden melakukan tugasnya, responden menceritakan apa yang telah dilakukan dan dicatat oleh moderator. Hal tersebut biasanya dilakukan dengan memutar video rekaman tentang kegiatan yang dilakukan oleh responden sebelumnya [13].

\section{METODOLOGI PENELITIAN}

Terdapat empat tahapan dalam melakukan evaluasi pada add-ins yang telah dibuat. Diantaranya adalah 1) evaluasi dengan metode RTA, 2) evaluasi dengan kuesioner SUS, 3) melakukan wawancara pada responden, dan 4) membuat rekomendasi perbaikan sistem. Gambar 6 adalah tahapan penelitian yang dilakukan.

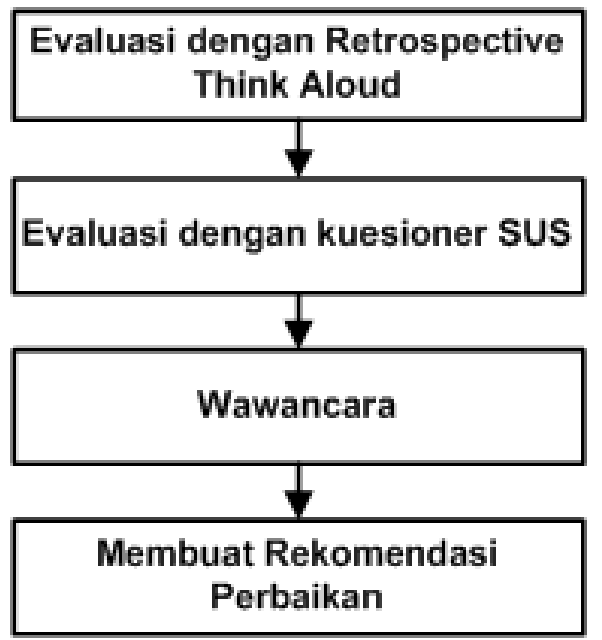

Gambar 6. Tahapan penelitian

\section{Subjek Penelitian}

Add-ins yang dikembangkan digunakan untuk membantu dosen dalam mencari, membuat, dan mempublikasikan materi. Maka dari itu, subjek penelitian untuk mengukur usability add-ins ini adalah para dosen. Dosen yang digunakan sebagai subjek penelitian berjumlah 8 orang yang berasal dari Fakultas Teknik dan Kejuruan Universitas Pendidikan Ganesha. Dosen dipilih adalah dosen yang secara aktif telah menggunakan e-learning.

\section{Evaluasi dengan Metode RTA}

Pada evaluasi RTA, responden diberikan beberapa tugas yang harus diselesaikan dan langsung berhadapan dengan sistem. Sebelum responden diberikan tugas, moderator memberikan pengarahan awal tentang apa tujuan responden dalam menggunakan sistem. Moderator mendampingi responden selama evaluasi dilakukan. Selama responden melaksanakan tugas, aktivitas pengguna direkam dengan menggunakan perangkat lunak perekam layar komputer. Aktivitas responden juga dicatat oleh moderator.

Setelah seluruh tugas diselesaikan, responden dan moderator bersama-sama menyaksikan rekaman yang dilakukan sebelumnya. Dari rekaman tersebut, responden diminta untuk menceritakan apa yang dilakukan olehnya. Responden juga diminta untuk menjelaskan apa saja permasalahan atau kesulitan yang dihadapi dalam menggunakan sistem. Moderator mencatat semua permasalahan yang dihadapi oleh responden.

\section{Evaluasi dengan Kuesioner SUS}

Setelah evaluasi RTA selesai dilakukan, pengguna diberikan kuesioner SUS untuk dijawab berdasarkan pengalaman responden dalam menggunakan sistem. Kuesioner terdiri dari 10 pertanyaan. 5 pertanyaan positif, dan 5 pertanyaan negatif. Responden memberikan respon dengan mencentang kolom respon yang memiliki skor dari 0-5, di mana 0 adalah respon terendah, dan 5 adalah respon tertinggi. Jika pertanyaan adalah pertanyaan negatif, maka respon dikurangi dengan 4. Setiap respon selanjutnya dikalikan 2,5 sehingga setiap respon akan bernilai 0 hingga 10. Dengan begitu, total skor akan berkisar antara 0 hingga 100 untuk setiap responden. Skor SUS adalah total skor responden yang dijumlahkan lalu dibagi dengan jumlah responden. 


\section{Wawancara}

Wawancara dilakukan untuk mengetahui halhal yang belum dapat dikonfirmasi pada evaluasi RTA maupun SUS. Wawancara dilakukan setelah dua evaluasi sebelumnya selesai. Wawancara berkisar tentang bagaimana pengguna menggunakan sistem secara umum. Wawancara bersifat konfirmasi sehingga tidak ada instrumen khusus dalam melakukan wawancara. Hasil wawancara akan digunakan sebagai bahan untuk membuat rekomendasi perbaikan sistem dengan hasil evaluasi RTA.

\section{Membuat Rekomendasi Perbaikan}

Rekomendasi perbaikan dibuat berdasarkan hasil evaluasi RTA dan wawancara. Dari kedua evaluasi tersebut, dilakukan identifikasi terhadap permasalahanpermasalahan yang muncul selama evaluasi dilakukan. Permasalahan-permasalahan tersebut dipilah dan dikelompokkan berdasarkan kesamaan permasalahan antar responden. Berdasarkan identifikasi permasalahan tersebut, dibuat rekomendasi untuk memperbaiki sistem. Rekomendasi berupa struktur navigasi dan desain antarmuka yang diperbaiki.

\section{HASIL DAN PEMBAHASAN}

Terdapat 3 metode yang digunakan dalam mengevaluasi add-ins ini, yaitu Retrospective Think Aloud (RTA), System Usability Scale (SUS), dan wawancara. Setelah evaluasi dilakukan dibuatkan rekomendasi berdasarkan hasil evaluasi.

\section{Evaluasi Retrospective Think Aloud (RTA)}

Pada evaluasi RTA, responden ditugaskan untuk menyelesaikan 3 buah tugas dalam menggunakan sistem. Terdapat 8 orang responden yang diminta untuk menyelesaikan tugas-tugas tersebut. Berikut ini adalah tugas yang diberikan:

T1: Cari menu "Moodle Power-Link" di Microsoft PowerPoint, lalu login dengan akun e-learning dengan menggunakan username dan password yang diberikan.

T2: Download sebuah dokumen di elearning dan edit di PowerPoint

T3: Cari materi baru dengan fitur "search", pilih salah satu materi yang diperoleh, lalu masukkan materi tersebut ke slide.

T4: Upload dokumen yang telah diedit lagi ke e-learning
Semua aktivitas yang dilakukan oleh pengguna direkam dan selanjutnya diputar kembali untuk melakukan evaluasi. Dari rekaman tersebut, dikonfirmasi kembali ke pengguna sehingga diperoleh informasi tentang permasalahan apa yang terjadi dalam menggunakan add-ons yang dikembangkan. Tabel 2 adalah beberapa permasalahan yang terdeteksi dalam menggunakan add-ins.

Tabel 2. Daftar permasalahan pada evaluasi RTA

\begin{tabular}{|c|c|}
\hline Tugas & Permasalahan \\
\hline T1 & Tidak ada permasalahan berarti \\
\hline $\mathrm{T} 2$ & Tidak ada permasalahan berarti \\
\hline T3 & $\begin{array}{l}\text { - } \\
\text { Navigasi: Pada saat responden } \\
\text { sudah ada di dalam salah satu } \\
\text { menu, responden bingung } \\
\text { untuk mencari menu "search" } \\
\text { atau "upload". Beberapa saat } \\
\text { kemudian, responden baru } \\
\text { sadar bahwa harus menekan } \\
\text { tombol "Back to Main Menu" } \\
\text { di bagian atas Add-ons. } \\
\text { Antarmuka: Pengguna sering } \\
\text { salah dalam memasukkan } \\
\text { materi yang diinginkan, karena } \\
\text { setiap sebuah materi di-klik, } \\
\text { materi tersebut langsung } \\
\text { masuk ke slide. Menurut } \\
\text { pengguna, lebih baik diberikan } \\
\text { satu tombol khusus untuk } \\
\text { memasukkan materi tersebut } \\
\text { ke slide di setiap materi yang } \\
\text { diperoleh oleh fitur pencarian. }\end{array}$ \\
\hline T4 & $\begin{array}{l}\text { - } \\
\text { Navigasi: Pada saat responden } \\
\text { menu, responden bingung } \\
\text { untuk mencari menu "search" } \\
\text { atau "upload". Beberapa saat } \\
\text { kemudian, responden baru } \\
\text { sadar bahwa harus menekan } \\
\text { tombol "Back to Main Menu" } \\
\text { di bagian atas Add-ons. }\end{array}$ \\
\hline
\end{tabular}

\section{Evaluasi System Usability Scale (SUS)}

SUS digunakan untuk melihat tingkat kepuasan pengguna dalam menggunakan sebuah sistem. Terdapat 10 butir kuesioner yang dijawab oleh responden. Butir soal dalam kuesioner tersebut adalah standar, sehingga tidak ada modifikasi dalam kuesioner yang diberikan. Berdasarkan jawaban oleh responden, skor rata-rata SUS adalah sebesar 75,63. Sistem dapat dianggap memuaskan oleh pengguna jika rata-rata nilai SUS di atas 68. Nilai rata-rata SUS yang diperoleh adalah 75,63 dimana nilai tersebut lebih besar dari 68, sehingga dapat disimpulkan bahwa pengguna merasa puas 
Tabel 3. Hasil evaluasi SUS

\begin{tabular}{|c|c|c|c|c|c|c|c|c|}
\hline SUS & \multicolumn{9}{|c|}{ Responden } \\
\hline Pertanyaan & $\mathbf{1}$ & $\mathbf{2}$ & $\mathbf{3}$ & $\mathbf{4}$ & $\mathbf{5}$ & $\mathbf{6}$ & $\mathbf{7}$ & $\mathbf{8}$ \\
\hline 1 & 5 & 7,5 & 7,5 & 5 & 5 & 10 & 5 & 7,5 \\
\hline 2 & 10 & 10 & 7,5 & 10 & 7,5 & 10 & 10 & 10 \\
\hline 3 & 7,5 & 10 & 7,5 & 7,5 & 10 & 10 & 7,5 & 10 \\
\hline 4 & 5 & 2,5 & 5 & 5 & 2,5 & 5 & 5 & 5 \\
\hline 5 & 7,5 & 7,5 & 7,5 & 7,5 & 7,5 & 10 & 10 & 7,5 \\
\hline 6 & 7,5 & 10 & 10 & 7,5 & 7,5 & 7,5 & 5 & 7,5 \\
\hline 7 & 5 & 7,5 & 7,5 & 7,5 & 5 & 7,5 & 7,5 & 5 \\
\hline 8 & 10 & 10 & 7,5 & 10 & 10 & 10 & 7,5 & 10 \\
\hline 9 & 7,5 & 7,5 & 10 & 7,5 & 10 & 10 & 7,5 & 5 \\
\hline 10 & 7,5 & 7,5 & 5 & 5 & 7,5 & 5 & 7,5 & 7,5 \\
\hline Total & 72,50 & 80,00 & 75,00 & 72,50 & 72,50 & 85,00 & 72,50 & 75,00 \\
\hline
\end{tabular}

Skor SUS = 75,63

dengan add-ons yang dikembangkan. Tabel 3 adalah rekap hasil evaluasi SUS.

\section{Hasil Wawancara}

Wawancara dilakukan untuk mendapatkan masukan dari pengguna tentang add-ons yang dikembangkan. Dari hasil wawancara, sebagian responden mengungkapkan bahwa ada beberapa repetisi pada navigasi add-ins. Sebagai contoh, daftar kuliah dan daftar materi ditampilkan pada halaman unduh dokumen dan di halaman unggah dokumen. Kedua halaman tersebut memiliki tampilan yang sama, hanya saja memiliki fungsi yang berbeda. Beberapa responden mengusulkan untuk menyatukan halaman tersebut, namun terdapat menu untuk melakukan unduh materi dan unggah materi di halaman yang sama. Dari hasil wawancara juga ditemukan bahwa responden menginginkan adanya tombol-tombol berupa ikon. Add-ins yang dikembangkan memang hanya menggunakan link berupa tulisan untuk berinteraksi dengan antarmuka. Dari sisi fungsionalitas, rata-rata responden mengaku add-ins ini dapat membantu dalam membuat sebuah materi dengan lebih cepat.

\section{Identifikasi Permasalahan}

Berdasarkan evaluasi RTA, SUS, dan hasil wawancara, terdapat beberapa permasalahan yang berhasil diidentifikasi. Permasalahan pertama adalah beberapa pengguna merasa bingung untuk kembali ke menu utama. Hal ini terjadi karena menu untuk kembali ke menu utama hanya berupa link pada bagian atas setiap halaman. Maka dari itu, dibutuhkan sebuah tampilan yang lebih informatif dam mudah untuk dikenal untuk kembali ke menu utama.

Permasalahan kedua adalah tampilan yang berulang pada fungsi unduh dan fungsi unggah dokumen. Kedua fungsi tersebut memiliki tampilan yang hampir sama, namun memiliki fungsi yang berbeda. Kedua halaman tersebut dapat digabungkan menjadi satu dan menambahkan fungsi unduh dan unggah di halaman yang sama. Dengan menggabungkan kedua halaman menjadi satu, maka dibutuhkan struktur navigasi baru yang lebih sederhana. Fungsi unduh dan unggah juga harus memiliki tampilan yang berbeda jika kedua fungsi tersebut digabungkan pada halaman yang sama. Maka dari itu, sebuah antar muka baru untuk fungsi unduh dan unggah juga dibutuhkan.

Permasalahan ketiga adalah fitur pencarian konten materi pembelajaran yang belum optimal. Beberapa pengguna merasa sering salah memasukkan materi yang diinginkan karena materi langsung masuk ke slide jika di-klik. Menurut pengguna, seharusnya terdapat tombol yang informatif untuk yang berfungsi untuk memasukkan materi ke slide.

\section{Rekomendasi Perbaikan}

Berdasarkan identifikasi permasalahan, dibuatlah suatu rekomendasi sebagai bahan perbaikan add-ins.

\section{1) Tampilan Kembali ke Menu Utama}

Rekomendasi pertama adalah membuat tampilan untuk kembali ke menu utama. Pada 
setiap halaman dibuatkan sebuah tombol dengan bentuk tanda panah ke kiri dan berisi tulisan "Main Menu". Tombol tersebut diberi warna yang cerah sehingga mudah untuk diidentifikasi oleh pengguna. Di samping tombol tersebut terdapat nama halaman yang sedang aktif sehingga pengguna lebih mudah untuk mengidentifikasi di mana pengguna sedang bekerja. Gambar 7 adalah tampilan yang direkomendasikan.

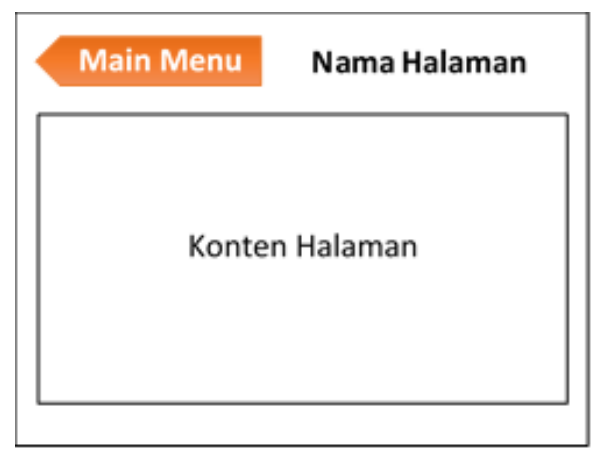

Gambar 7. Rekomendasi menu kembali ke halaman utama

\section{2) Struktur Navigasi}

Rekomendasi kedua adalah perbaikan struktur navigasi. Gambar 8 adalah struktur navigasi add-ins sebelum ada rekomendasi. Struktur navigasi terlihat cukup tinggi, di mana di 3 menu di menu utama yaitu unduh dokumen, unggah dokumen, dan pencarian materi. Pada menu unduh dokumen dan unggah dokumen terdapat halaman yang sama, yaitu daftar mata kuliah/kursus yang di dalamnya terdapat daftar materi. Yang membedakan adalah fungsi dari kedua halaman, yaitu pertama berfungsi untuk mengunduh materi, dan yang kedua untuk mengunggah materi. Dengan struktur navigasi tersebut, terdapat duplikasi halaman daftar kuliah yang sebenarnya dapat dijadikan satu.

Berdasarkan temuan di atas, dibuat sebuah rekomendasi untuk menyederhanakan struktur navigasi pada add-ins. Gambar 9 adalah rekomendasi struktur navigasi yang diajukan. Menu utama hanya memiliki 2 buah menu, yaitu pencarian materi dan daftar mata kuliah. Pada menu daftar mata kuliah, terdapat halaman daftar mata kuliah yang di dalamnya terdapat daftar materi pada mata kuliah yang dipilih. Pada halaman tersebut, terdapat dua fungsi utama yaitu fungsi untuk mengunduh materi dan fungsi untuk mengunggah materi. Kedua fungsi tersebut sebelumnya terpisah pada halaman yang berbeda satu sama lain.

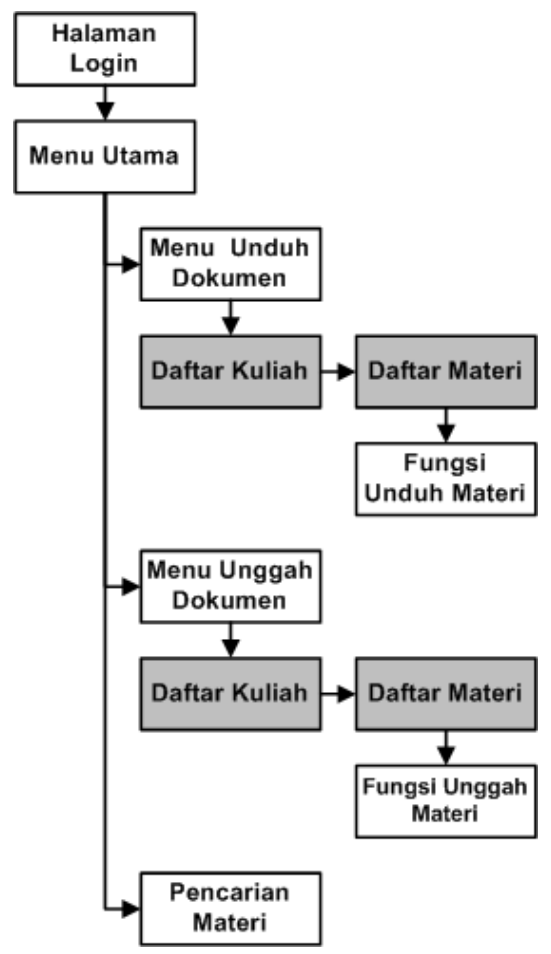

Gambar 8. Struktur navigasi sebelum ada rekomendasi

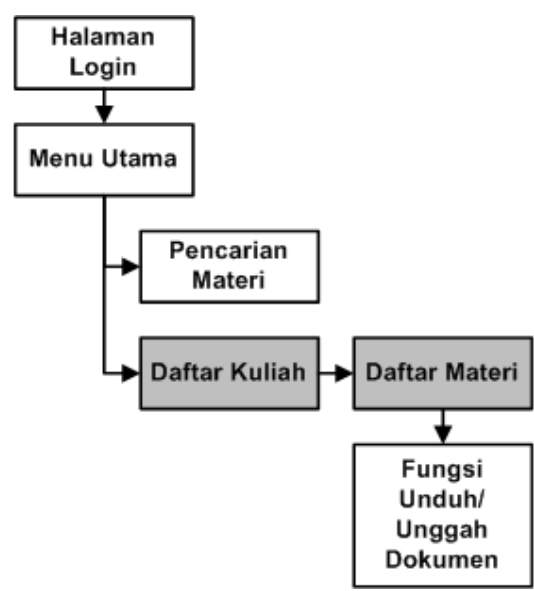

Gambar 9. Rekomendasi struktur navigasi

3) Antarmuka Unduh dan Unggah Materi Rekomendasi ketiga adalah perubahan antarmuka unduh dan unggah materi. Sebelumnya fungsi unduh dan unggah materi dipisahkan di halaman yang berbeda seperti terlihat pada Gambar 3 dan Gambar 4. Rekomendasi untuk permasalahan tersebut adalah dengan menggabungkan kedua fungsi di halaman yang sama. Dengan menggabungkan kedua fungsi tersebut, maka hanya dibutuhkan satu halaman daftar materi. Pada halaman tersebut, setiap materi akan berisi tombol "unduh materi" yang diwakili 
dengan tanda panah ke bawah. Pada setiap topik, akan berisi tombol "unggah materi" yang diwakili dengan tanda panah ke atas. Jika fitur unggah materi ditekan, maka materi akan secara otomatis diunggah dan ditaruh pada topik bersangkutan. Rekomendasi dapat dilihat pada Gambar 10.

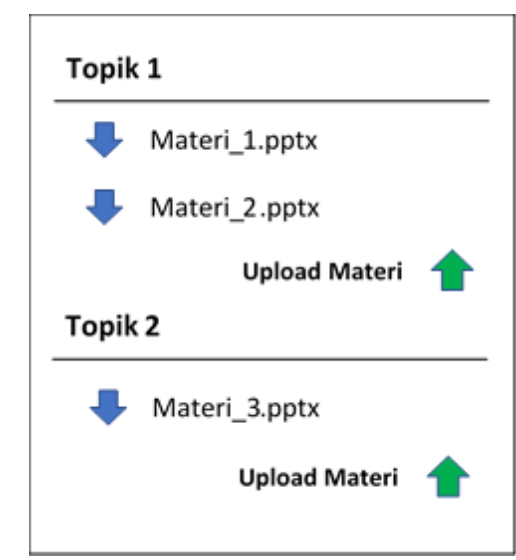

Gambar 10. Rekomendasi antarmuka halaman kursus dan fitur unduh/unggah materi

\section{4) Antarmuka Pencarian Materi}

Rekomendasi keempat adalah membuat tampilan pencarian materi yang dapat meminimalisasi kesalahan memasukkan konten materi ke slide. Hal tersebut dapat dilakukan dengan menambahkan tombol pada setiap hasil pencarian. Tombol tersebut berupa tanda panah ke arah slide (ke kanan) dengan warna yang cerah. Dengan tampilan ini, jika pengguna mengklik teks hasil pencarian, maka teks tidak langsung dimasukkan ke slide. Teks hanya akan masuk ke slide jika pengguna mengklik tombol di sebelah kiri teks hasil pencarian. Gambar 11 adalah rekomendasi antar muka hasil pencarian.

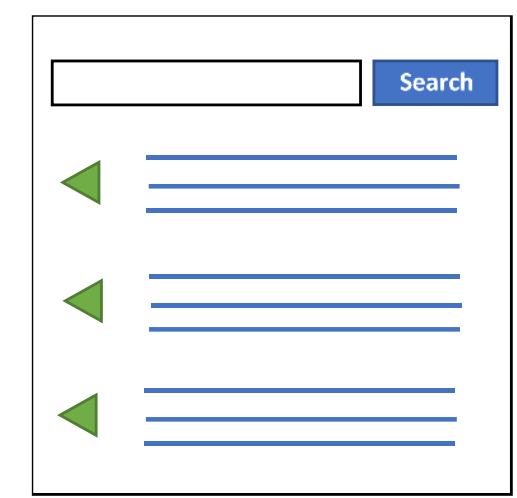

Gambar 11. Rekomendasi antarmuka hasil pencarian

\section{SIMPULAN}

Add-ins ini dibuat untuk mengintegrasikan Sistem Manajemen Pembelajaran dan Sistem Rekonstruksi Materi. Dengan add-ins tersebut, pengguna dapat melakukan pembuatan materi, pencarian konten materi, dan publikasi materi dengan melalui satu aplikasi. Usability testing dilakukan untuk mengetahui bagaimana respon pengguna dalam menggunakan add-ins ini. Dari evaluasi yang dilakukan, terdapat beberapa permasalahan yang berhasil diidentifikasi seperti navigasi dan antar muka add-ins. Dari identifikasi permasalahan tersebut, telah dibuatkan rekomendasi untuk memperbaiki add-ins di masa mendatang. Berdasarkan rekomendasi tersebut, diharapkan dapat meningkatkan kepuasan pengguna dalam menggunakan add-ins ini.

\section{DAFTAR PUSTAKA}

[1] H. B. Santoso and Z. A. Hasibuan, "Pengaruh Faktor Pemicu Terhadap Tingkat Partisipasi Diskusi dalam Student Centered E-Learning Environment," in Seminar Nasional Aplikasi Teknologi Informasi (SNATI), 2007, vol. 2007, no. Snati.

[2] A. A. G. Y. Paramartha, I. K. Purnamawan, N. W. Marti, and P. H. Suputra, "Sistem Rekonstruksi Materi Pembelajaran Berbasis Objek Pembelajaran Granular," in Seminar Nasional Vokasi dan Teknologi (SEMNASVOKTEK)., 2017, pp. 99104.

[3] L. W. P. Peute, N. F. de Keizer, and M. W. M. Jaspers, "The value of Retrospective and Concurrent Think Aloud in formative usability testing of a physician data query tool," $J$. Biomed. Inform., vol. 55, pp. 1-10, 2015.

[4] M. E. Khan and F. Khan, "A Comparative Study of White Box, Black Box and Grey Box Testing Techniques," Int. J. Adv. Comput. Sci. Appl., vol. 3, no. 6, pp. 12-15, 2012.

[5] R. P. Bringula and A. N. De Leon, "The Role of Trust in Web-Based Election System Usability," Proc. 16th Int. Conf. Inf. Integr. Web-based Appl. Serv. - iiWAS '14, pp. 196-199, 2014.

[6] ISO 9241-210, "Ergonomics of human-system interaction." International Standards 
Organization, 2010.

[7] I. S. Junus, H. B. Santoso, R. Y. K. Isal, and A. Y. Utomo, "Usability evaluation of the student centered eLearning environment," Int. Rev. Res. Open Distance Learn., vol. 16, no. 4, pp. 62-82, 2015.

[8] A. Bangor, T. Staff, P. Kortum, and J. Miller, "Determining What Individual SUS Scores Mean," J. usability Stud., vol. 4, no. 3, pp. 114123, 2009.

[9] N. Harrati, I. Bouchrika, A. Tari, and A. Ladjailia, "Exploring user satisfaction for e-learning systems via usage-based metrics and system usability scale analysis," Comput. Human Behav., vol. 61, pp. 463-471, 2016.

[10] Usability.gov, "System Usability Scale (SUS)." [Online]. Available: https://www.usability.gov/how-toand-tools/methods/system-usabilityscale.html. [Accessed: 12-Oct-2018].

[11] T. Alshammari, O. Alhadreti, and P. J. Mayhew, "When to Ask Participants to Think Aloud: A Comparative Study of Concurrent and Retrospective Think-Aloud Methods," Int. J. Hum. Comput. Interact., no. 6, p. 48, 2015.

[12] A. M. Gray and H. Wardle, "Observing gambling behaviour using think-aloud and video technology A methodological review," Natl. Cent. Soc. Res., no. February 2012, 2013.

[13] Usability.gov, "Running a Usability Test." [Online]. Available: https://www.usability.gov/how-toand-tools/methods/runningusability-tests.html. [Accessed: 12Oct-2018]. 